\title{
A language of hope from a homiletical perspective
}

\author{
C J A Vos
}

(University of Pretoria)

\section{ABSTRACT}

\section{A language of hope from a homiletical perspective}

The purpose of a sermon is to give hope when it appears that there is none. This hope must be like a light, breaking through the darkness. Wolfgang Amadeus Mozart's music is a transition from darkness to light. His music helps us to look further than darkness, suffering and death. In the Old Testament, there is a reference to Psalm 42/43 and also the perspective of hope in God, despite the dark circumstances in life.

The hope that bubbles out of Romans has christological, pneumatological, cosmological and anthropological dimensions. From this theological foundation, a sermon becomes a messenger of hope. In a sermon, language is the key to hope. In order to understand the language of the Bible, (especially the Old Testament), consideration needs to be given to the origins and function of mythological language. The language of a text and the language of a homiletician is further woven together by metaphors. The language of the homiletician must also carry the language of love. Imagination is an undeniable part of a sermon and imagination can create hope.

\section{ANGLE}

People go to church with high expectations. They attend church services to be given hope. They are often let down by their expectations, but they keep going to church. In a homiletic sense, the sermon is the sheath of hope. The aim of the sermon is to deliver hope, against all odds.

\section{HOPE CONVEYS DARKNESS AND LIGHT}

Hope is like a lily in muddy water. The lily flowers in this water and like the lily, hope grows in distressful and muddy circumstances. Hope can exist in mud. Hope lives off beauty, and in mud. But hope also reminds us of our frailty.

There is darkness and light in everyone's life; there are the dark hours, but also the light moments; the failures, but also the successes. There is extreme poverty, but there are also endless 
riches; there are often tears accompanying laughter; there is aging and youthfulness; with gain, there is loss; alongside birth is also slow death. To make matters worse, not everyone is equally affected by misery. There can be hope in a hopeless situation. There is praise in lamentation (cf. Ps 13). A person is still able to praise God, despite being extremely low. In times of difficulty, praise given by believers is sometimes more sincere and profound than in times of prosperity.

Wolfgang Amadeus Mozart was attuned to this ambiguous concept of lamentation and praise, light and shade, which he was able to translate musically. There is no balance of opposites in his music, but often a masterful disruption of balance. Like the sunrise, which fails to chase away the darkness; like joy that overcomes pain, without the pain ceasing; like a 'yes', which sounds stronger, but where the 'no' is always present. Mozart's music expresses real life with its dichotomy and the continual transition from shade to light (and never the other way around). Herein lies Mozart's irresistible charm (cf. Gruber and Brügge 2005; Leopold 2005; Sinkovicz 2005).

Mozart's own life was very different - there were few moments of light and many moments of shade. He died in poverty, was given a pauper's burial and the location of his grave is still unknown. But his music continues to console. His clarinet concerto in A major , $\mathrm{K}$ 622, which was finished between mid-October and mid-November 1791, was amongst Mozart's last compositions (Wiese 2005:360). The Adagio is moving; the plaintive sounds of the clarinet touch one so deeply that it leaves one speechless. Mozart experienced much hardship, but in the end, left us music that gives us a perspective beyond the suffering of life and death.

In the homily, as in life, we cannot sacrifice hope's bright side. We cannot live without hope. We need to cling to hope. In other words, hope needs to embrace us. We are able to identify with Rainer Maria Rilke (1966:234) in his tenth elegy:

Und wir, die an steigendes Glück

denken, emfänden die Rührung,

die uns beinah bestürtzt, wenn ein Glückliches fällt. 


\section{FROM DESPAIR TO HOPE}

\subsection{An Old Testament perspective}

The Psalms comprise five books (cf. Vos 2005). Ps 42/43 are part of Book II and Ps 84 is part of Book III. Ps $42 / 43$ form one psalm (Zenger 1997:478; Schuman 2004:5-6; Schaper 2004:14-17). It is part of the series of the Psalms of Korah. The children of Korah, who are the gatekeepers of the temple, are part of a choir that is able to sing in a particular high tone (Schuman 2004:11). On textual level, Psalms 42/43 present the dramatic progress from alienation and desolation to newfound trust and closeness (Schuman 2004:9).

The psalm series Psalms 84-89 forms the Psalms of Korah. Psalm 84 opens the series with travelling as its theme (Ps 84-88, with the exception of Psalm 86). Psalm 42/43 are echoed in Psalm 84 (cf. Schaper 2004:27, 29, 31-38; Zenger 2000:517, 520-521). Psalm 42 is the beginning of the journey. In terms of this structure, Psalms 42/43 and Psalm 84 correspond as the opening psalms of their respective compositions. Both these psalms are individual prayers of longing for an encounter with the God of Zion, before whom, the petitioner desires to appear (Hossfeld \& Zenger 2000:520).

In Psalm 42 (Zenger 1997:479; Schuman 2004:10-11), we hear the voice of someone who experiences his sojourn, as though it were exile and chaos. This sojourn is one of threat and hostility.

There is only one escape for the poet, when despair and fear descend on him - yearning for God (verse 1). "As the deer pants for streams of water, so my soul pants for you, O God. My soul thirsts for God, for the living” (Ps 42:2, 3). The streams for which the deer yearns are mentioned again in the second stanza (verse 8 ). The same intense yearning for God is evident in Ps 84:3. This is also a yearning for the Living God (Ps 84:3) and it is a yearning that is kept alive by a painful memory (Ps 42:5; Schaper 2004:55). When the poet sees his life being played out before him, he realises how he has been taken into God's house. He then walks out in front of a crowd that is filled with praise.

When will he appear in front of God again (verse 3)? This is a question filled with uncertainty (Schuman 2004:8). His doubt is reinforced by the enemy's daily mockery, "Where is your God?" (verse 4). In the second stanza, the biting mockery is continued, 
"Where is your God?” (verse 11). The oppressors make the poet feel like God has deserted him (verse 10). This formulation is even stronger in verse 2: "Why have you rejected me?" The scorn and despair are all the more painful to him, because he feels that God has turned His back on him. He, who is thirsty, drowns because he does not experience God as his Rock. God lets the waves wash over him, and he has no one to hold onto (Ps 42:8).

There is a movement in this Psalm from yearning and desolation to the fulfilment of hope and gratitude. This movement is supported by faith (Ps 42:6, 12; 43:5. Cf. Ps 84:13). Faith enables one to appeal to God. "Vindicate me, O God, and plead my cause against an ungodly nation" (Ps 43:1). The repetition of this request corresponds with, "Send forth your light and your truth" (Ps 43:3). The words 'your light' and 'your truth' contrast with 'your waves and breakers' (Ps 42:7). The 'light' disperses fear and calamity (cf. Ps 27:1). For the poet, this is a sign that God regards him with love and benevolence (cf. Ps 31:17; Zenger 1997:484). This 'faith' in God, which the poet hopes for/aspires to, is the faith experienced by God's people, which has also been experienced by individuals throughout history (Zenger 1997:484-485). God's loyalty is contrasted with his feelings of doubt. The doubt is replaced with hope. In this way, his longed-for reality comes closer (Schuman 2004:9).

Fulfilment is attained at the Holy Mountain and God's altar (Ps 43:3, 4). Hope is fulfilled in the liturgy. "By day, the Lord directs his love; at night, his song is with me - a prayer for the God of my life" (Ps 42:8). This liturgical line, which is present in the middle of Psalms 42 and 43, requires our attention. The holy name, Yahweh, is placed here between Elohim (10 times; 2 times 5) and Elohim, (11 times), followed by a closer qualification (such as "your God, my God, God of my life”) (Schuman 2004:4). Therefore, I support Niek Schuman's (2004:4) supposition that we are dealing here with the formula from the temple liturgy. The poet will praise God as his Helper and this help is experienced as personal: "he is my God" (Ps 43:5). Even the sparrow has found a home, and the swallow a nest for herself, where she may have her young - a place near your altar (Ps 84:3). Like a snail in his shell, the faithful find their rest in God. 


\subsection{A New Testament perspective in Romans 8}

\subsubsection{Theological contours}

Romans 8 is a rich landscape with intriguing theological contours. In Romans 1:18-3:20, both the Jews and the Greeks are subjected to God's judgement (Wilckens 2005:173-180). There is a new vocabulary in Romans 5:1-8:39: pneuma, agape, elpis, doxa tou theou, zoe, katalagge, eirene; the presence of sun-compositions (verses 22, 26 and 29), while a new confessional style (first person plural) takes the discourse in a different direction (Beker 1994:27). Rom 8 unfolds the motifs of Romans 5:1-11. Common root words are present in both parts: agape, pneuma, elpis en doxa. Romans 5:15 juxtaposes the hope for the glory of God with the suffering in the world. This theme is further developed in Rom 8:17-30 (Beker 1994:28). The theme of hope is built on two pillars: that of Christology and Pneumatology.

\subsubsection{Christology}

Romans 8 can be interpreted as an extended footnote of the exclamation, "Thanks be to God - through Jesus Christ our Lord" (Rom 7:25) (Klauck 1999:90. Cf. Wilckens 1980:119-121; 2005:208). Man's salvation lies outside of himself - in Christ. Jesus Christ has acquitted us from judgement for our sins. Paul uses juridical terms in Romans 8 to explain the acquittal. The acquittal is based on the impossible. In order to enable the acquittal, Jesus Christ had to take on the likeness of sinful humanity (Rom 8:3). God sent his Son to the reality and the realms of sin (Käsemann 1974:209; Wilckens 1980:125; 2005:210). In the words of the poet, Van Wyk Louw (1987:139), God's little eagle fell into our anxious flesh. This had to be done in order to condemn sin.

Christ is our Acquitter, and in Heaven, at God's seat of judgment, He is our Mediator. We no longer have to fear God as a vindicating Judge. We may call Him Father now, and we may hope that due to the intercession of the Holy Spirit and his Son, we will be acquitted of all sin, even those which are hidden and unknown (Klauck 1999:94. Cf. also Vos 2005 on Ps 19:13).

\subsubsection{Pneumatology}

Christ's acquittal is received through faith. According to Romans 8, having faith means to be in Christ (Rom 8:1). The Spirit of Christ gives this gift of faith. In the words of Karl Barth (1947:89-101), the 
sermon is the third configuration of the Word. The acquittal is announced in the sermon. In other words, people are invited to be part of the acquittal process. These events are dynamic in that the Holy Spirit, through words, convinces people to accept the acquittal in Christ. In Rom 8:16, the Spirit of God contacts the human spirit. He testifies to the childhood that was promised to us at our christening (Käsemann 1974:219; Klauck 1999:91). The Holy Spirit makes us Christ's property and His co-heirs (Rom 8:9, 17). This spirit of acceptance of the children makes us utter: "Abba, Father!" (Rom 8:15).

\subsubsection{Cosmology}

Pneumatology is a fountain of hope for creation. Against its will, creation has been subjected to the bondage of decay. Mankind has caused the ruin of creation (Rom 8:20) and as a result, creation is immersed in 'frustration'. In Greek, the word 'frustration' is at the beginning of the sentence and in this way, it is accentuated (Vos 1990:76). Nature in its entirety is defenceless against the power of sin. We hear the groans of creation everywhere. We sully, soil and ruin Mother Nature.

Oh, the agony of the earth - the agony of the earth, like a little dog's bowels, he bleeds, the earth bleeds: pockmarked old man's land, out of every wrinkle streams blood.

$\mathrm{O}$, the earth is decaying - the earth is decaying like garbage scraps.

Indeed we have succeeded in effectively reducing Mother Earth into a wasteland (Louw 2006:19).

The Holy Spirit gives creation the hope of liberation (Rom 8:19-21). Creation waits in hope for this freedom (Rom 8:19). The reference to waiting in hope is present six times in Paul (three times in Rom 8). This hope is for the revelation of Christ (1 Cor 1:7; cf. Fil 3:20); justice (Gal 5:5) and acceptance (Rom 8:23).

There are three 'sighing' movements in Romans 8:19-26. The three concentric circles form a crescendo: from creation (verse 22) to 
the creation of the Christians (verse 23) to the sighing Holy Spirit (verse 26).

Creation sighs because of the imperfection of this current age. Creation's sighs are the lamentation and the call of a creature expressing its longing for completion (Klauck 1999:92; Wilckens 2005:214-215). The hope for liberation and freedom makes nature in its entirety sigh with 'the pain of expectation'. The metaphor of a woman giving birth implies pain, but importantly, there is the feeling of hope, despite the pain: there is hope for the birth of a new heaven and earth. Listen to creation's sighs. Despite the pain, there are hopeful sighs. Listen how the waves,

glass trains filled with water (Breytenbach 1977:139)

time and time again crash to their end

on the beach.

We must listen when it rains at night and the earth feasts greedily. Amidst all the sighs, we must hear the hope of nature and create hope ourselves.

\subsubsection{Anthropology}

Human depravity is described in Romans (Rom 1). Everyone is a sinner (Rom 3:24). This creates the tension in Romans. To be human is to be a sinner and a beggar, but also to be holy (Rom 8:27). To have faith in God's acts through Jesus Christ and the Holy Spirit is in our best interest. We are holy in God's eyes (Klauck 1999:94). This has its foundation in Christology. It is the Spirit that allows us to experience salvation. We have the 'first-fruits' of the Spirit (Rom 8:23). We have received the gift of the 'firstfruits' or the first instalment towards our future completion.

The concept of 'firstfruit' comes from the Jewish harvest festival, i.e. the first offerings from the wheat and wine harvest (Ex 22:29; 23:19; Lev 2:12; 23:10; Num 15:15:20; 18:12, 30; Deut 26:22; 2 Chron 31:15; Neh 10:37, 39; Mal 3:8). The reference to the Spirit as being the gift of the firstfruit is intended to conjure up an image of the Pentecost for the readers (the festival of the weeks; Ex 23:16; 34:22; Deut 16:9-12)

The offering of the firstfruit illustrates that the entire harvest belongs to God and is dedicated to him. The believers' gift of the Holy Spirit, which lives in every believer, is the first of what we will own in Christ and what we will receive. Like the first ripening of an 
acorn, like the first grain winnowed on the threshing floor, the Spirit is the first guarantee that the entire harvest will be gathered. (Vos 1990:83). This is bestowed on our hearts at our christening (Klauck 1999:92) and is the reason we sigh in anticipation of completion. We sigh in anticipation of our acceptance, because we are still trapped in transience (verse 23). We live with our sighs. The sighs are sighs of hope in the face of suffering (verse 18), trouble, hardship, persecution, famine, nakedness, danger and the sword (verse 35). The Holy Spirit makes us sigh in the face of despair. He uses the sermon to make us sigh. If only sermons comprised more sighs, and were less triumphant!

Then there is the third surprising sigh. We are sometimes short of a spiritual breath. We do not know how and what to pray for (Rom 8:26). We do not know 'what to' and 'how' to pray according to God's will (Lambrecht 1992:117). Hence, the Holy Spirit acts on our behalf. The verb, 'sunantilambanetai', is known in antiquity as 'take in', assist in supporting, lend a hand, come to the aid of'. The 'sun' part makes this act intense. The image of the Spirit shouldering the burden, which our weakness imposes on us, is quite a vivid one.

The Holy Spirits' sighs are described as 'wordless' or 'unpronounceable'. However, this does not mean that the Holy Spirits' sighs are mute. If that were the case, the climactic rise of the three sighs would be lost (Klauck 1999:92). 'Wordless' could also mean that it is not articulated clearly (Wilckens 1980:160; Klauck 1999:92). We cannot ignore the contradiction: we do not know how to and what to pray for, that is why the Holy Spirit comes to our aid. The Holy Spirit takes on our animal-like weakness. This weakness reflects our defencelessness as creatures. It is also because we do not know why and how to pray in the right way (Klauck 1999:92). The right way implies an alignment with God's will. Our insights are limited; the motives behind our actions are mostly veiled. The Holy Spirit helps us navigate this subconscious territory. He lets God's will be done in our lives.

This dynamic interaction also happens in a different way. God, alone, has access to the secrets of the heart (Rom 8:27. Cf. 1 Sam 16:7; 1 Ki 8:39; Ps 7:10; Jer 17:9-10). He knows the darkness and inner workings of our lives. God also encounters his Spirit in our hearts. He guarantees true understanding (Käsemann 1974:233-234; Klauck 1999:93). 


\section{THE SERMON AS VESSEL OF HOPE}

There are strong homiletic impulses in Psalms 42/43, which make the sermon a vessel of hope. The congregation brings their despair, anxiety, fear, doubt, sadness and uncertainties to the place of public worship. Some of the people have palaces and riches, but they are all 'strangers' and 'drifters'. The theme of 'exile' is continued in the New Testament (1 Pt 2:11: Heb 11:3). The stranger (paroikos) is contrasted with the katoikoi - the permanent occupants of a country that have full citizenship. We are the paroikoi and as such, our citizenship is in heaven, where we expect our Saviour, Jesus Christ, to reside (Phlp 3:20). In the words of Noordmans, we are not yet ready for heaven, but too late for earth. Our restlessness will continue, until we find peace in the Fatherland, the house of the Father (Heb 11:13, 14).

Two of the most torturous feelings experienced by most people, are loneliness and God's absence. In times of suffering the scornful question, "Where is your God?" will echo. It sometimes feels like God has turned his back on us. All that is left is a memory of encountering God in liturgy. I have seen and experienced Him there. I'm still hearing the roar of the festival.

The burning question in homiletics is about God. God must once again have an identity, a face in the sermon. He must be experienced in the present. Homiletics must give hope to the hopeless. This can be achieved by encouraging the listener's longing for God. The listener must experience a burning thirst for God.

God's light must shine through during the sermon and faith in Him must be like a rock. The sermon must chase away chaos and darkness and must convince people to trust in God. When a sermon succeeds in achieving this, a song of praise is sung for God, the helper. The homiletician must lead the congregation to the landscape of the New Testament, where the question, “where is your God?", echoes on a cross. The christological depth of the sermon states: "Your God is on the cross! But as your Helper, your Saviour." He has been made to rise from the dead / has risen from the dead, to banish chaos and darkness. The Pneumatology of this homiletic perspective makes us realise that God is our Paraclete, who is our deliverer of hope. The house of the Father has much space to live and hope in abundance. 
Romans 8 presents a framework for the sermon as a vessel of hope. In the context and experience of hopelessness, Christology and Pneumatology unlock hope. Everyone, who is in Christ, has hope. A homiletical Christology expands on Psalms 42/43 and Romans 8 and creates the perspective that there is hope in Christ. To 'be in Christ' means to have a bond with Christ and to trust him. He is the Helper and the one who gives hope. A homiletic Pneumatology opens a window to the influence of the Holy Spirit on people and creation. The Holy Spirit gives hope in many different, surprising ways. He is the first gift. He makes creation and the believers sigh, and He too, sighs. The sermon opens peoples' ears to the sighs. The sermon teaches people to live off the sighs - sighs and hope.

\section{LANGUAGE AS A KEY OF HOPE}

\subsection{Mythological language}

Language manifests on two different levels in a sermon, i.e. the written language contained in the text and the spoken language of the homiletician.

I will now only make a few observations about language. When reading and translating a text from antiquity, the homiletician must consider the strangeness, uniqueness and the rules of the alien language landscape, especially in terms of religious texts and language as mythological language.

Irsigler (2004:13-14) provides us with an elaborate theory of myth. He summarises the characteristics of this genre in the following seven points:

(a) A 'myth' can fundamentally (i.e. on a primary level) be described as a narrative mode of expression, which was orally transmitted. On a secondary level, it is a literary text type, which is significant for the collective self-understanding of a specific culture. A myth can occur in the form of a traditionally significant narrative, a history or a narrative sequence, which describes an incident, the order of events or an important happening. Whatever it may be, it is converted into different images.

(b) Numinous beings, that is to say a deity or a number of deities, participate in the narrated event. They can act within the scope of their relationship to one another or even in relation to human beings. 
(c) The event, which is narrated, namely in the form of the myth, normally takes place in circumstances open to change that is to say - there is a movement from a position of instability towards a (positive or negative) position of stability.

(d) These events are being told as non-recurring incidents, even when they refer to repetitive events occurring either in nature or in the human world.

(e) The time of the event, as being told in the myth, has an extra-temporal character. It stands in direct contrast to human time, which can be understood either as historical time or as contemporary time. The myth thus happens in pre-historical times, primitive times, or proto-typical times during which current conditions of existence are established. The story being told or described thus has a pre-historical character.

(f) The sphere of the event is in principal not restricted to one single space. It, on the other hand, has numinous qualities, e.g. the mountain of the gods, the garden of God, the temple, etc. This space is often outside the directly accessible, namely Heaven or the underworld. It, nevertheless, can have a direct influence on human lives.

(g) In a functional sense, the myth proclaims basic human experiences against the background of a secret and threatening world. The events in the myth are examples of human existence and activity. The myth describes the establishment of natural order. It thus accounts for the present reality - it substantiates, it legitimises, it explains, it interprets.

At this point, it seems appropriate to establish a minimal startingpoint from which the analysis of texts from the Psalter can proceed (cf. Groenewald 2007). Poetry, by means of the medium of language, constitutes a world, which simultaneously presents a counter-world. Poetical texts generate a new world of meaning which is based on distinctive subject matters, traditions and motives.

Poetry utilises mythical imagery and mythical constellations in order to present the world, which is experienced as a profound dimension. The readers and listeners of such poetry engage in this profundity the moment when their own realities and the poem's reality coalesce. This poetical constitution of the religious counterworld undoubtedly utilises 'mythical' language - especially when its 
aim is to master the broken-ness, as well as radical changes taking place in both collective as well as individual lives.

In the Psalms of Israel we encounter the 'mythical' in a variety of ways. Through the medium of language, the Psalms lead their readers into an alternative encounter with the transcendental reality, which differs from the traditional encounter the cult offered them. These 'mythical' texts, therefore, do not need the cult, ritual and sacred space anymore as 'time' and 'space' in order to enter into the world of the divine. These texts, rather, represent the 'space' and 'time' of the divine presence. This statement leads us to an important hermeneutical principle, which should be emphasised. The exegete should always be aware of the fact that these texts integrate the customary (i.e. the everyday) into the 'mythical' (Zenger 1999:234). In order to interpret the Psalms as religious poetry, he/she should always pay exact attention to this integrated perspective. It seems that all religious realities are based upon the assimilation of the metamorphoses of different realities. We thus cannot have conscious representations of God, which do not contain mythical aspects.

Psalm 121 is an example of mythological language. This Psalm is not referring to literal mountains. Mountains in those days were the homes of the gods. The poet is asking if his help is coming from the gods. His answer is then: "No, my aid comes from God, who created heaven and earth" (Vos 2005: 255-256).

\subsection{The language of the homiletician}

Languages suffer from epidemics, with certain regularity, that for years infect their vocabulary, prosody, syntax, and even their logic (Paz 1985:189). Octavio Paz's writings about language can also be seen as relevant to the language of the sermon. Sometimes the disease contaminates the entire liturgy. The epidemic that contaminates the language, is language that is bloodless and unimaginative. One cliché follows the other.

The homiletician is a wordsmith. On Sundays, the preacher aids the followers of Christ by means of poetic activity. The preacher makes (poiein) words, approximately fifteen-hundred of them, on a Sunday morning, three-million in a career, and over the long haul of ministry, he or she speaks into existence an alternative world (Lischer 2005:104). In the words of the poet (Van Heerden 1987:84) the homiletician is 
... the candlemaker

the challenger of darkness,

who creates a song from a flame

This is exactly what the homiletician must do - he/she must create a song in darkness.

A text is like a 'texture of meaning' (textum), with many entangled threads, which, singularly, also carries meaning (Rossouw 1981:48). Every text suggests several patterns of interpretation, and the preacher may weave a different one every year (Lischer 2005:74). The preacher winkles out the text until its life-changing power is disclosed. This is hard work, because not every text gives up its Winkel without a fight (Lischer 2005:63).

Human beings do not only communicate with one another using language, but also about 'something' (Rossouw 1981:31). In this case language is a tool for imparting information.

\subsubsection{Metaphors as the sparks of life}

Metaphors are the sparks ignited by imagination. This is illustrated in the film Il Postino (The Postman). A postman is the bearer of news - sometimes bad news -, which is likely when an envelope has one of those windows. Sometimes the news may be good, as when the letter comes from a friend or loved one. One of the characters in Il Postino is an enthusiastic postman, Mario Ruoppolo, who dutifully does his bicycle rounds, delivering mail on the Italian island of Cala di Sotto. One of the recipients of his mail lives on the upper slopes of a steep hill. He is the famous Chilean poet, Pablo Neruda. The poet is living in exile for political reasons. One day, Mario falls in love with a beautiful girl, Beatrice Russo. He finds himself staring at her, speechless, with admiration. He would like to declare his love for her, but he feels he needs Pablo, the poet, to supply the words. Neruda teaches the postman that he is capable of creating metaphors, not merely licking stamps.

Metaphors can never have fixed meanings, nor can their effect be predicted with any degree of accuracy (For an exposition of metaphors, see Doyle 2004:43-47; Bons 2004:236-237). Metaphors create 'unfettered language,' (Langage délié, Ricoeur 1975:152 et seq), which releases people from the usual meanings of words, and moves them towards hitherto undiscovered shades of meaning. The 
living metaphor brings renewal to language (Morgenthaler 2002:130; Van Leeuwen 2002:70).

This renewal and its new insights come about because a metaphor is normally a word or expression used in an unusual context (see Grözinger 2004:101-102). Living metaphors redescribe reality in such a surprising way that we feel touched by them.

Metaphors are not quasi-descriptive, as if the true description could overtake them at some time, but instead, they are redescriptive (cf. Ricoeur 1975a).

Metaphors are explosive and their force hurls people towards new insights and blasts open new worlds. Metaphors that enlighten the faithful also enable them to experience surprises and moments of awe in their everyday life.

\subsubsection{The functions of metaphors}

Aristotle (Carson 2000:30) distinguishes between three kinds of words: strange, ordinary and metaphorical. Strange words give us a headache, ordinary words convey familiar meanings, and metaphors offer us new insights (Carson 2000:30). In the following sections some functions of metaphors are explained (for a detailed discussion on this matter, cf. Vos 2005).

\subsubsection{Metaphors create tension}

In order to appreciate the impact and freshness of metaphors, we need to examine certain functions of metaphors. A metaphor helps us to begin to understand the unknown, in terms of the known (Van Huyssteen 1986:159). Metaphors do more than 'name' things; they give us access to the objects that are being referred to (Van Huyssteen, 1997:188). They create a bridge, an interaction between the 'matter' and the 'image'. The image gives access to the matter.

It is characteristic of the metaphor, that it creates linguistic tension (Ricoeur 1975b:77, 79, 92-93, 95). It offers a 'stereoscopic vision' and links the two halves, the matter and the image (e.g. God and rock, Ps 18:2) in a complex tension that recognises both the similarities and the differences. This is the source of a dynamic interaction between the matter and the image. The interaction that accompanies the use of metaphors takes place at the level of both words and meanings. The interaction brought about by metaphors 
makes room for imagination. The result is that metaphors transcend the boundaries set by rigid reflection (Van Huyssteen 1997:212).

The function of the metaphor is paradoxical, in that something that exists simultaneously also does not (Ricoeur 1979:27). The metaphor always whispers, "It is/it is not" (Lischer 2005:119). The tension inherent in a metaphor simultaneously serves to confirm and deny that something is the case. According to Ricoeur, there is an implicit negation in every positive metaphorical statement (Ricoeur 1977:221-224, 255-256). The metaphor, God is a rock, confirms that there is a relationship between God and a rock (permanence, strength, shelter), but it still retains the 'and is not' implication. God is not literally a rock. The real meaning emerges from the conflict between the concepts 'God' and 'rock' (cf. Van Leeuwen 2002:6970). The conceptual framework of the listener is the instrument with which it gives the God-as-rock metaphor associations of permanence, strength and security. This creates new perspectives of God, new experiences of him in the divine service, all of which should be reflected upon in society. The metaphorical tension is maintained, because God is not always experienced as 'a rock' in everyday life.

What are the implications of this kind of metaphorical reflection for homiletics? Sometimes God is and at other times, he is not! God cannot be pinned down in a sermon, as he moves mostly outside of it. Great caution is therefore necessary, if the homiletician wants to try to trace God's 'face' in the sermon.

\subsection{Language of love}

Carlos Fuentes (2004:1) writes movingly about the secret of love. In Yucatan, you never see the water. It flows underground, beneath a fragile sheath of earth and limestone. Occasionally, that delicate Yucatec skin blossoms in eyes of water, in liquid ponds - the cenotes - that attest to the existence of a mysterious subterranean current. For Fuentes, love is like those hidden rivers and unexpected streams of Yucatan. Love must underpin the language of the sermon, like hidden rivers and unexpected streams. Therefore, love must be reinvented - that is obvious (Arthur Rimbaud).

The language of the sermon is the language of love. The love of the Father, Son and the Holy Spirit is declared to the bride by means of the sermon. The Holy Spirit makes words spark, love spark. However, he does not do this without the preacher (Van Ruler 
1971:190). The preacher must first hear and understand what the Holy Spirit wants to say to the bride, before he can facilitate the dialogue between the groom and the bride.

God declares His love for the bride through the language of love. The aim of this declaration is to inspire mutual love. The homiletician's declaration in the Name of God aspires to encourage in the listener, love for God and his fellow man.

However, words of love can also have a distancing effect - the words of love between a groom and his bride belong only to them and a stranger is not interested in their wordplay. In the context of the groom-bride metaphor, this means that a stranger must first become part of the community of love, before he/she is able to rejoice about the language of love.

A distinctive feature of the language of love is its playfulness. Where there is playfulness, there is also humour and irony (for irony, cf. Eco 2005:212). Real humour captures the heart and the ear of the listener. Irony teaches us not to take ourselves, or others too seriously. The homiletician must remember that it is the language of love that conquers hearts.

\section{IMAGINATIVE SERMONS}

Artists are imaginative and creative people and theologians can learn from them. Theology must take artists' words, images and sculptures seriously. Imagination and creativity are not only reserved for artists, they are open to all of us, because:

You are like a rich man entering Heaven

through the ear of a raindrop. Listen now again (Heaney 1996:1).

The concept of a sermon as an open work of art leaves space for creativity. Creativity is a homiletic necessity (cf. Den Dulk 1998; Nicol 2005:67). Elisabeth Grözinger (2002:175) rightly states, "Whoever is afraid of creativity while preparing a sermon does not really trust the energy of the Biblical talk about God." In the search for meaning, words appear, as the means of imagination, for the most that words can do (since they produce emotional effects) is to lead us to imagine (Eco 2005:199).

Creativity will not fall into the homiletician's lap (although it occasionally does!). A homiletician requires knowledge and skill, together with an inner freedom and a sense of security. In the process 
of the creation of sense, the preacher, as well as the listener, must be sensitive to the potential for imagination and the function of the words.

Creativity is something other than fantasy. Fantasy is an escape from reality, whereas creativity expands and enriches reality. Creativity is like a painter, who has painted some apples. Once he has painted them, they are no longer apples, but patches of colour and shapes suspended in space; in passing we register them as 'apples' and the next time we see real apples, because we look at them with an altered perspective. It is creativity that conjures apples out of patches of colour and shapes and which make us see more than apples. Creativity is the source of imagination. Imagination allows us to reach deeper layers of our inner being than we could ever have accessed with our reason (Siertsema 1998:379). In the sermon, hope can be fuelled through imagination.

\section{A LIFE OF, AND FROM HOPE}

In the conclusion, I would like to give you a few morsels for your journey.

The liturgy is the space where hope can be experienced and celebrated. God takes us into the future with his Words, the future for which he, himself, stands (Rossouw 1981a:86). Through the hope, which is granted in the sermon, we learn that the future has already started.

The world is the space where life can be achieved from hope. It is the place where the promises of the sermon are lived through and experienced. Hope carries people during their journey.

\section{Consulted literature}

Barth, K 1947. Kirchliche Dogmatik. Fünfte Auflage. Zürich: Evangelischer Verlag.

Beker, C 1994. The Princeton Seminary Bulletin. Supplementary Issue, nr 3, 26-32.

Bons, E 2004. Ehemetaphorik in Hosea 2, 4-25 - Elemente, Funktion, Hintergründe, in Irsigler, H (Hg.). Mythisches in biblischer Bildsprache. Gestalt und Verwandlung in Prophetie und Psalmen. Freiburg, Basel, Wien: Herder.

Breytenbach, B 1977. Blomskryf. Emmarentia: Taurus.

Carson, A 2000. Men in the off hours. Alfred A Knopf: New York. 
Fuentes, C 2004. This I believe. An A-Z of a writer's life. London: Bhonsburg Publishing Plc.

Carson, A 2000. Men in the off hours. New York: Alfred Knopf.

Den Dulk, M 1998. Vjf kansen. Een theologie die begint bij Mozes. Zoetermeer: Uitgeverij Meinema.

Doyle, B 2004. Words with teeth and childbearing men: metaphors in Psalm 7, in Human, D J and Vos, C J A. (eds.). Psalms and Liturgy. Journal for the Study of the Old Testament Supplement Series 410. London New York: T \& T Clark, 41-61.

Eco, D 2005. On Literature. Translated from the Italian by Martin McLaughlin London: SCM Press.

Groenewald, A 2007. From myth to theological language, in Human, D J (ed.). Psalms and Mythology. BHBOT, London/New York: $\mathrm{T} \& \mathrm{~T}$ Clark (forthcoming).

Grözinger, A 2002. Toleranz und Leidenschaft. Über das Predigten in einer pluralistischen Gesellschaft. Gutersloh Gutersloher Verlagshaus Gerd Mohn.

Grözinger, E 2004. Preaching as a lifelong process of creating perspectives, in Immink, G \& Stark, C (eds.). Preaching: Creating Perspective. Utrecht: Vandenhoeck \& Ruprecht, 167-183.

Gruber, G \& Brügge, J 2005. Das Mozart Lexikon. J Laaber: Laaber Verlag.

Heaney, S 1996. The Spirit Level. London: SCM Press.

Hossfeld, F-L \& Zenger, E 2005. Psalms 2: Psalms 51-100. (Tr by Linda Maloney from the original German). Hermeneia. Minneapolis, MN: Fortress Press.

Irsigler, H 2004. Vom Mythos zur Bildsprache. Eine Einführung am Beispiel der "Solarisierung" JHWHs, in Irsigler, H (Hg.). Mythisches in biblischer Bildsprache. Gestalt und Verwandlung in Prophetie und Psalmen, 9-42 (QD 209) Freiburg: Herder.

Käsemann, E 1974. An die Römer. Tübingen: JCB. Mohr.

Klauck, H-J 1999. Vom Zauber des Anfangs. Biblische Besinnungen. Werl: Dietrich-Coelde-Verlag.

Lambrecht, S J 1992. Het verscheurde 'ik' en zijn bevrijding. Leuven: Acco Uitgeverij.

Leopold, S (Hg.). 2005. Mozart Handbuch. Metzler: Bärenreiter-Verlag.

Lischer, $\mathrm{R}$ 2005. The end of words. The language of reconciliation in a culture of violence. Grand Rapids, Michigan / Cambridge, U.K.: William B. Eerdmans Publishing Company.

Louw, G 2006. Kraai. Kaapstad Pretoria: Human \& Rousseau.

Louw, Van Wyk, N P 1987. Tristia. Kaapstad: Nasionale Pers. 
Morgenthaler, C 2002. Systematische Seelsorge. 3. Auflage. Stuttgart: Verlag W. Kohlhammer.

Nicol, M 2005. Einander ins Bild setzen. Dramaturgische Homiletik. (2., durchgesehene und überarbeitete Auflage.) Göttingen: Vandenhoeck \& Ruprecht.

Paz, O1985. One earth, four or five words. Reflections on contemporary history. Manchester: Carcanet Press.

Ricoeur, P 1975. Parole et symbole, in Revue des science religieuses 49, 142161.

-, 1975a. La métaphore vive. Paris: Editions du Seuil.

-, 1975b. Biblical Hermeneutics, in Semeia 4, 29-145.

-, 1977. The rule of metaphor. Multi-disciplanary studies of the creation of meaning in language. London: Routledge and Kegan Paul.

-, 1979. Naming God, in USQR 34/4, 15-27.

Rilke, R M 1996. Gedichte 1910 bis 1926. Frankfurt und Leipzig: Insel Verlag.

Schaper, J 2004. Wie der Hirsch lechzt nach frischem Wasser. Studienz P 42/43 in Religionsgeschichte und kirchlicher Praxis. Neukirchen-Vluyn: Neukirchener Verlag.

Schuman, N 2004. Het hert, het water en het heimwee. Vrije Universiteit Amsterdam: Amsterdam.

Siertsema, B 1998. Verbeelding in de liturgie, in Oskamp, P. \& Schuman, N A (reds.). De weg van de liturgie. Zoetermeer: Uitgeverij Meinema, 379-387.

Sinkovicz, W 2005. Mozart Seine Musik. Wien: Die Presse Verlagsgesellschaft.

Van Heerden, E 1987. Amulet teen die vuur. Kaapstad: Tafelberg-Uitgewers.

Van Huyssteen, W 1986. Teologie as kritiese geloofsverantwoording. Pretoria: RGN-Uitgewery.

-, 1997. Essays in Postfoundationalist Theology. Grand Rapids/Michigan/ Cambridge, U.K: Eerdmans Publishing Company.

Van Leeuwen, M 2002. De onalledaagse taal van de liturgie, in Barnard, M \& Schuman, N A (reds.). Nieuwe wegen in de liturgie. Zoetermeer: Uitgeverij Meinema, 65-81.

Van Ruler, A A 1971. "Continuïtent in de prediking," in: Theologisch Werk. Deel 2. Nijkerk: Uitgeverij G F Callenbach.

Van Wyk Louw, N P 1987. Tristia (2 ${ }^{\text {nd }}$ ed.). Kaapstad: Human \& Rosseau.

Veldsman, D P 1993. Religieuse ervaring as herinneringsvolle verbeelding, in Scriptura 42, 1-16.

-, 1994. When reality has become a pale reflection of our images. Imagining faith in Christ in a postmodern context, in Skrif en Kerk 15(1), 120-140. 
Vos, C J A 1990. Hoop in lyding, in Vos, C J A en Müller, J C God in ons Lyding. Pretoria: Orion

-, 2005. Theopoetry of the Psalms. Pretoria: Protea Book House

Wiese, H 2005. Das Mozart Lexikon. Herausgegeben von Gruber, G und Brügge, J Laaber: Laaber Verlag.

Wilckens, U 1980. Der Brief an die Römer. Neukirchen-Vluyn: Neukirchener Verlag.

-, 2005. Theologie des Neuen Testaments. Teilband 3. Neukirchen -Vluyn: Neukirchener Verlag.

Zenger, E 1997. Die Nacht wird leuchten wie der Tag. Psalmenauslegung. Freiburg/Basel/Wien.

-, 1999. "Das Mythische in den Psalmen 84 und 85," in: Lange, A., et. Al. (Hg.) 1999. Mythos im Alten Testament und seiner Umwelt. Festschrift für Hans-Peter Müller zum 65. Geburtstag. (BZAW 278.). Berlin: Walter de Gruyter, 233-251.

-, 2000. Psalmen, in Hossfeld, F-L \& Zenger, E (Hrsg.), Psalmen 51-100. Freiburg/Basel/Wien: Herder Verlag. 